\title{
REVIEW: MIKOREMEDIASI LOGAM BERAT
}

\section{Mycoremediation of Heavy Metal: A Review}

\author{
Andri Kurniawan ${ }^{1, \star}$, Nuraeni Ekowati ${ }^{2}$ \\ ${ }^{1}$ Jurusan Budidaya Perairan, Fakultas Pertanian, Perikanan, dan Biologi, \\ Universitas Bangka Belitung \\ ${ }^{2}$ Jurusan Biologi, Fakultas Biologi, Universitas Jenderal Soedirman \\ *E-mail: andri_pangkal@yahoo.co.id
}

\begin{abstract}
Heavy metals contamination is a main issue which has negative impacts to environment and organisms. Various methods have been developed to reduce such pollutants, including utilization of organisms' capability in order to minimize the contamination. Mycoremediation is one of remediation process in contaminated environment using fungi and its reduction mechanisms, involving intracellular, as well as extracellular system. There are some species of fungi that are frequently used as remediator agents, for example Aspergillus sp., Fusarium sp., Penicillium sp., Phanerochaete sp., Trichoderma sp. There are some methods that have been used for heavy metal reduction mechanisms such as biosorption, bioaccumulation, bioprecipitation, bioreduction, and bioleaching.
\end{abstract}

Keywords: Mycoremediation, fungi, heavy metal, biosorption, bioaccumulation

\section{ABSTRAK}

Kontaminasi logam berat adalah suatu permasalahan utama yang berdampak negatif bagi lingkungan dan juga makhluk hidup. Berbagai metode telah dikembangkan untuk mereduksi cemaran, termasuk memanfaatkan kemampuan organisme untuk meminimalkan kontaminan tersebut. Mikoredemiasi adalah salah satu proses remediasi cemaran di lingkungan dengan melibatkan fungi beserta mekanisme reduksinya, baik secara intraselular maupun ekstraselular. Beberapa jenis fungi yang sering dijadikan agen remediator antara lain Aspergillus sp., Fusarium sp., Penicillium sp., Phanerochaete sp., Trichoderma sp. Beberapa prinsip yang digunakan untuk menghilangkan logam berat antara lain biosorpsi, bioakumulasi, biopresipitasi, bioreduksi, dan bioleaching.

Kata kunci: Mikoremediasi, fungi, logam berat, biosorpsi, bioakumulasi 


\section{PENDAHULUAN}

Salah satu permasalahan lingkungan yang menjadi perhatian masyarakat global adalah cemaran logam berat yang mengkontaminasi alam dan manusia. Logam berat merupakan kontaminan yang terpenting di dalam lingkungan (Tangahu et al. 2011) dan menjadi permasalahan serius bagi lingkungan sekarang ini (Fu dan Wang 2011). Keberadaan logam berat dalam jangka waktu yang lama dapat menjadi ancaman signifikan bagi kesehatan diakibatkan akumulasi pada lingkungan dan sepanjang rantai makanan (Rajendran et al. 2003; Mkumbo 2012; Verma dan Gupta 2013). Pada konsentrasi berlebih, logam berat memiliki efek toksik bagi organisme hidup (Chaalal dan Zekri 2005), termasuk hewan (Lone et al. 2008), pertanian (Jaiswal 2011), dan kemudian menjadi ancaman serius bagi kesehatan manusia (Rai 2008).

Beberapa jenis logam berat seperti kadmium $(\mathrm{Cd})$, tembaga $(\mathrm{Cu})$, timbal $(\mathrm{Pb})$, nikel $(\mathrm{Ni})$, seng $(\mathrm{Zn})$, dan lain sebagainya terdeteksi berada di tanah dan lingkungan perairan (Dixit et al.. 2015). Penelitian lain menunjukkan bahwa arsenik (As), tembaga $(\mathrm{Cu})$, timbal $(\mathrm{Pb})$, timah $(\mathrm{Sn})$, dan $\mathrm{Zn}$ berada di tanah dan ditransfer ke tanaman melalui akar, daun, dan bunga (Ashraf et al. 2011) serta pada beberapa kasus, manusia terpapar logam berat melalui ikan tercemar logam berat seperti besi (Fe), seng ( $Z n)$, tembaga $(\mathrm{Cu})$, mangan $(\mathrm{Mn})$, kadmium $(\mathrm{Cd})$, dan timbah $(\mathrm{Pb})$ di dalam organ ikan yang dikonsumsinya (Saeed dan Shaker 2008; Ahmad dan Al-Mahaqeri 2015).

Kontaminasi logam berat di dalam lingkungan perlu ditangani dengan baik untuk mereduksi toksisitasnya. Namun, metode penanganan membutuhkan biaya tinggi dikarenakan sulit untuk memisahkan toksisitasnya dari lingkungan (Krishnani dan Ayyappan 2006; Wang et al. 2012). Namun, aktivitas biologis dipercaya mampu menjadi metode alternatif untuk mengurangi cemaran logam berat (Dhokpande dan Kaware 2013), khususnya menggunakan mikroorganisme yang memiliki kemampuan untuk menghancurkan sejumlah kontaminan (Akhtar et al. 2013) dan mengakumulasinya sebagai biosorben (Javanbakht et al. 2014). Metode ini dikenal sebagai bioremediasi, yaitu suatu metode dengan melibatkan peran mikroorganisme dalam pereduksian cemaran yang terdapat di alam sehingga kondisi lingkungan dapat dimanfaatkan kembali secara optimal, aman, sehat, dan berkelanjutan.

Artikel ini bertujuan untuk mengkaji kemampuan fungi sebagai mikoremediator di dalam mereduksi logam berat.

\section{BIOREMEDIASI}

Bioremediasi telah dikenal luas dan menjadi teknologi dekontaminasi yang dipandang lebih aman, lebih bersih, harga murah, lebih efektif, mudah dilakukan, efisiensi tinggi, dan ramah lingkungan (Kensa 2011; Bhatnagar dan Kumari 2013; Kulshreshtha et al. 2014a, Javanbakht et al. 2014) sehingga dapat dimaknai sebagai teknologi hijau (green technology) di dalam sistem manajemen lingkungan (Hlihor dan Gavrilescu 2012). Secara umum, aplikasi bioremediasi menggunakan organisme hidup, khususnya mikroorganisme yang digunakan untuk mereduksi polutan (Samal dan Kotiyal 2013). Agen biologi di dalam proses bioremediasi disebut bioremediator.

Mikroorganisme membawa materi genetik alami, kemampuan biokimia, dan sifat fisiologis yang membuatnya mampu berperan sebagai agen yang ideal di dalam remediasi polutan (Prakash et al. 2013). Mikroorganisme tersebut menggunakan sel atau metabolit mereka berupa enzim untuk mengembalikan lingkungan tercemar ke kondisi aslinya dengan cara biosorpsi yang dapat terjadi melalui proses kompleksasi, kelasi, koordinasi, presipitasi, pertukaran ion, atau proses oksidatif-reduktif (Kumar et al. 2010; Kumar et al. 2011; Sayyed dan Patel 2011; Ahemad 2012; Juwarkar et al. 2014). Selain itu, mikroorganisme tersebut menghancurkan kontaminan (Adams et al. 2015) dan menjadikan logam tersebut sebagai kofaktor enzimatis (Remy et al. 2013).

Sejumlah logam berat atau trace element seperti kobalt (Co), tembaga (Cu), kromium (Cr), besi (Fe), arsenik (As), nikel $(\mathrm{Ni})$, dan seng $(\mathrm{Zn})$ dibutuhkan sebagai nutrien esensial serta memegang peranan penting bagi proses kehidupan organisme. Namun pada konsentrasi yang tinggi di atas ambang batas, maka logam-logam berat tersebut berpotensi menjadi racun (Pede 2012). 
Berbagai mikroorganisme telah menunjukkan kemampuan resistensinya terhadap logam berat di dalam air, tanah, maupun limbah industri. Mikroorganisme menggunakan logam berat tersebut sebagai mikronutrien dan digunakan dalam proses redoks, untuk menstabilkan molekul melalui inteksi elektrostatis, sebagai komponen beberapa enzim, dan pengaturan tekanan osmosis. Mikroorganisme telah beradaptasi terhadap keberadaan logam esensial maupun non esensial melalui proses pengembangan berbagai mekanisme resistensi, seperti keluar masuk melalui membran permiabel, aktivitas intra- dan ekstra-selular, transpor aktif, detoksifikasi enzimatis, dan reduksi ionik (Bruins et al. 2000; Dixit et al. 2015).

Bioremediasi menekankan pada kapasitas maupun aktivitas mikroorganisme heterotrofik anaerob maupun aerob dan aktivitas mikroorganisme dipengaruhi oleh sejumlah faktor fisika kimia lingkungan. Faktor-faktor yang dapat secara langsung berpengaruh di dalam proses bioremediasi antara lain sumber energi (donor elektron), akseptor elektron, nutrisi, $\mathrm{pH}$, temperatur, substrat atau metabolit penghambat, bentuk alami polutan (solid, semisolid, liquid, volatil, toksik atau tidak, organik atau anorganik), logam berat atau tidak, bentuk hidrokarbon aromatik polisiklik, atau bentuk lainnya, serta diversitas mikroorganisme (Boopathy 2000; Mani 2014).

\section{MIKOREMEDIATOR}

Kemampuan mikroorganisme untuk beradaptasi dengan kondisi lingkungan yang terkontaminasi telah banyak diteliti (Pushkar et al. 2015; Yin et al. 2015). Salah satu pendekatan yang telah dilakukan pada proses bioremediasi adalah mikoremediasi (Agunwamba et al. 2013). Mikoremediasi adalah suatu proses pendegradasian atau penghilangan toksik dari lingkungan yang tercemar dengan menggunakan fungi (Asiriuwa et al. 2013). Aktivitas degradasi atau deteriorasi yang dilakuan oleh fungi dikenal juga dengan istilah mikodegradasi atau mikodeteriorasi (Gupta dan Shrivastava 2014).

Mikoremediasi berperan penting pada penanganan limbah yang mengandung bahan toksi, seperti senyawa hidrokarbon, alifatik hidrokarbon (n-alkana: tridekana, tetradekana, pentadekana, heksadekana, heptadekana, oktadekana), senyawa poliklorinasi, logam berat, fenolik dan turunannya, senyawa sianida, pestisida (fungisida, insetisida, herbisida), logam, pewarna industri, lignin dan selulosa, serta xenobiotik yang berasal dari industri lainnya. Fungi memanfaatkan senyawa-senyawa yang berbahaya ini sebagai sumber nutrisi dan mendegradasi atau memfragmentasi polutan tersebut menjadi bentuk lebih sederhana yang bersifat non toksik (PinedoRivilla et al. 2009; Singh dan Sharma 2013).

Kemampuan mikoremediasi untuk mendegradasi sejumlah jenis substrat dan polutan bergantung pada enzim yang diproduksi (Kulshreshtha et al. 2014b). Sejumlah enzim yang diproduksi oleh fungi antara lain enzim pendegradasi lignin yang meliputi lignin perosidase (LiP), mangan peroksidase (MnP), enzim penghasil $\mathrm{H}_{2} \mathrm{O}_{2}$, lakkase, amilase, lipase, dan protease. Fungi memanfaatkan sejumlah pati, lemak, protein, pektin, selulosa, hemiselulosa sebagai sumber karbon. Bahkan, beberapa fungi mampu mengurai polimer komplek seperti keratin, kitin, ataupun lignin (Adenipekun dan Lawal 2012; Rhodes 2014; Gupta dan Shrivastava 2014).

Salah satu contoh fungi yang telah digunakan sebagai agen bioremediator adalah Saccharomyces cerevisiae yang mampu mengasorpsi cemaran ion timbal $\left(\mathrm{Pb}^{2+}\right)$ sebanyak $67-82 \%$ dan ion kadmium $\left(\mathrm{Cd}^{2+}\right)$ sebanyak $73-79 \%$ yang dilakukan selama 30 hari (Damodaran et al. 2011).

Selain itu, sejumlah fungi lainnnya yang telah diteliti dan digunakan sebagai agen mikoremediasi antara lain Aspergillus $\mathrm{sp}$, Fusarium sp., dan Penicillium sp. yang telah diuji memiliki toleransi terhadap logam berat seng $(\mathrm{Zn})$, timbal $(\mathrm{Pb})$, nikel $(\mathrm{Ni})$, serta kadmium (Cd) (Iram et al. 2009), Aspergillus flavus, A. niger, Fusarium solani, Penicillium chrysogenum resisten terhadap kromium (Cr) dan timbal (Pb) (Iram et al. 2012), fungi filamentus yang mampu mengabsopsi sejumlah logam berat seperti seng ( $Z n)$, kadmium (Cd), timbal $(\mathrm{Pb})$, besi (Fe), nikel (Ni), dan lainnya (Bishnoi dan Garina 2005), fungi dari jenis $A$. awamori, $A$. flavus, Phanerochaete chrysosporium, dan Trichoderma viride yang mampu toleran timbal $(\mathrm{Pb})$, kadmium $(\mathrm{Cd})$, kromium $(\mathrm{Cr})$, dan nikel (Ni) (Joshi et al. 2011), kelompok 
Trichoderma, yaitu jenis $T$. asperellum, T. Harzianum, dan T. tomentosum dalam penurunan kadmium (Cd) (Mohsenzadeh dan Shahrokhi 2014), serta termasuk juga Aspergillus niger dan strain Phanerocheate chrysosporium yang mampu menghambat dan mendegradasi Total Organic Carbons (TOC) (Maruthi et al. 2013).

\section{KEMAMPUAN TOLERANSI FUNGI}

Beberapa mekanisme dikembangkan oleh mikroorganisme untuk mentoleransi konsentrasi logam berat yang tinggi (Ahemad dan Malik 2011). Secara umum, kemampuan toleransi yang ditunjukkan oleh fungi terjadi melalui dua mekanisme, yaitu pemisahan secara ekstraselular melalui khelasi dan pengikatan dinding sel serta pemisahan intraselular fisik logam melalui pengikatan ke protein atau ligan lainnya untuk mencegahnya dari kerusaan target selular sensitif logam. Mekanisme ekstraselular berupaya menghindarkan sel dari masuknya logam, sedangkan sistem atau mekanisme intraselular bertujuan untuk mengurangi beban logam dalam sitosol (Anahid et al. 2011).

Mikroorganisme berperan di dalam pengendalian toksik logam berat di lingkungan dengan mengembangkan berbagai mekanisme pertahanan yang dapat mempengaruhi transformasi antara bentuk terlarut dan bentuk tidak terlarut. Mekanisme-mekanisme ini merupakan komponen yang terintegrasi secara alami di dalam siklus biogeokimiawi dan berpotensi dalam proses bioremediasi secara in situ maupun ex situ (Gadd 2000).

Mikroorganisme memegang kunci penting dalam peran geoaktif di biosfere, khususnya pada siklus biogeokimiawi dan biotransformasi unsur, tranformasi logam dan mineral, dekomposisi, pelapukan biologis, serta pembentukan tanah dan sedimen. Semua jenis mikroorganisme, baik prokariot atau eukariot serta asosiasi simbiotiknya dapat berkontribusi secara aktif di dalam fenomena geologikal (Gadd 2010).

Beberapa prinsip yang digunakan mikroorganisme untuk mereduksi logam berat antara lain biosorpsi, bioakumulasi, biopresipitasi, bioreduksi, dan bioleaching (Rao et al. 2002; Siswati et al. 2009; Damodaran et al. 2011; Chaturved et al.
2015; Dixit et al. 2015) yang dikerjakan melalui modifikasi kimiawi maupun dengan cara mempengaruhi bioavailabilitas kimiawi (Harms et al. 2011).

\section{Biosorpsi}

Remediasi cemaran logam berat yang dilakukan oleh mikroorganisme bertujuan untuk menghilangkan atau menurunkan mobilitas logam dan toksisitasnya, salah satunya melalui mekanisme biosorpsi (Congeevaram et al. 2007; Kumar et al. 2010; Rani et al. 2010). Biosorpsi dapat diartikan sebagai proses penghilangan logam dari suatu larutan dengan menggunakan bahan biologis (Gelagutashvili 2013). Biosorpsi juga dapat diartikan sebagai suatu proses penghilangan logam berat melalui pengikatan pasif ke biomassa tidak hidup dari suatu larutan dan mekanisme reduksi ini tidak dikendalikan secara metabolik. Biosorpsi merupakan proses penyerapan logam secara pasif oleh sel-sel mikroorganisme, biasanya adalah hasil dari formasi organik komplek-logam dengan penyusun dinding sel mikroorganisme, kapsul, atau polimer ekstraseluler yang disintesis dan diekskresikan oleh mikroorganisme tersebut. Hal ini berbeda dengan bioakumulasi yang dideskripsikan sebagai suatu proses aktif penghilangan logam berat yang membutuhkan aktivitas organisme hidup dan energi dibutuhkan di dalam proses penyerapan kation metalik (Davis et al. 2003; Gavrilescu 2004).

Proses biosorpsi melibatkan fase padatan (sorbent atau biosorbent, materi biologis) dan fase cairan (solvent, pada umumnya berupa) yang mengandung bahan-bahan tidak larut yang akan diserap (sorbate, ion logam) (Das et al. 2008). Berdasarkan ketergantungannya pada metabolisme, mekanisme biosorpsi dapat dikelompokkan menjadi mekanisme yang bergantung metabolisme (metabolismdependent mechanisms) dan mekanisme yang tidak bergantung dengan metabolisme (metabolism-independent mechanisms) (Pagnanelli et al. 2000).

Pengikatan logam tidak bergantung metabolisme (metabolism-independent metal binding) ke dinding sel dan permukaan eksternal hanya terjadi pada biosorpsi yang melibatkan biomassa tidak hidup (non-living 
biomass). Sedangkan pada metabolismindependent metal binding melibatkan proses adsorpsi seperti ionik, kimiawi, dan fisik oleh grup fungsional dinding sel biomassa. Biosorben memiliki berbagai sisi fungsional seperti karboksil, imidazole, sulfidril (thiol), amino, fosfat, sulfat, thioether, fenol, karbonil (keton), amida, gugus hidroksil, fosfonat, dan fosfodiester yang memiliki potensi (Gupta dan Mohapatra 2003; Javanbakht et al. 2014). Interaksi pasif dinding sel dengan ion logam dalam proses biosorpsi juga melibatkan makromolekul seperti lipid, protein, dan polisakarida yang terdapat pada permukaan dinding sel (Chipasa 2003).

Mekanisme biosorpsi merupakan proses kompleks yang dipengaruhi oleh beberapa faktor antara lain status biomassa (hidup atau tidak hidup, komposisi dinding sel), tipe biomaterial, sifat kimia larutan logam, serta kondisi lingkungan seperti $\mathrm{pH}$, oksigen terlarut, suhu, dosis biosorben, dan konsentrasi tinggi dari logam yang tidak berbahaya seperti sodium, kalsium, dan magnesium (Gavrilescu 2004; Hansda et al. 2015).

\section{Bioakumulasi}

Suatu organisme memiliki kapasitas untuk mengakumulasi logam berat lebih tinggi dibandingkan konsentrasi yang biasanya terdapat di lingkungan. Proses akumulasi ini dapat dikelompokkan menjadi biokonsentrasi dan bioakumulasi. Biokonsentrasi merupakan peningkatan secara langsung konsentrasi polutan sewaktu berpindah dari lingkungan ke suatu organisme. Sedangkan bioakumulasi adalah spesifik untuk organisme hewan dan merupakan manifestasi dari absorpsi polutan secara langsung yang terakumulasi melalui nutrisi yang ditambahkan (Smical et al. 2008). Bioakumulasi logam berat pada organisme hidup dideskripsikan sebagai suatu proses dan jalur migrasi polutan dari satu level trofik ke level lainnya, termasuk melalui rantai makanan sehingga dapat terakumulasi pada jaringan hingga organ dari suatu organisme pada level tertentu (Kouba et al. 2010; Akan et al. 2012; Alia et al. 2015). Bioakumulasi oleh mikroorganisme dapat juga diartikan sebagai interaksi aktif antara logam berat dengan sel mikroorganisme dimana ion logam akan berpenetrasi ke dalam sel-sel mikroorganisme tersebut (Chipasa 2003).

Keberadaan logam berat berbeda pada setiap level trofik di dalam suatu ekosistem, tergantung pada karakteristik bioakumulasi logam yang terkonsentrasi. Bioakumulasi logam berat terjadi secara aktif dan dikendalikan secara metabolik oleh organisme. Sedangkan bioavailabilitas logam berat, akumulasi, dan toksisitasnya tergantung pada variabel-variabel yang terdapat di lingkungan (Arunakumara dan Xuecheng 2008).

\section{Biopresipitasi}

Secara prinsip, di dalam proses presipitasi terjadi reaksi kimiawi terhadap logam berat sehingga terbentuk presipitat tidak larut dan kemudian presipitat tersebut dipisahkan melalui proses sedimentasi atau filtrasi (Fu dan Wang 2011). Presipitasi diikuti oleh proses koagulasi atau penggumpalan yang terjadi di dalam pembentukan presipitat hidroksida logam melalui penambahan bahan alkali untuk menghilangkan kation logam berat seperti $\mathrm{Pb}(\mathrm{II})$, $\mathrm{Cd}$ (II), Cu(II) dan Ni(II) (Dhakal et al. 2005).

Di dalam biopresipitasi, pereduksian logam berat menjadi presipitat dilakukan oleh mikroorganisme dalam kondisi anaerob dimana proses ini berbeda dengan biomineralisasi yang terjadi secara aerob (Martinez et al. 2007). Biopresipitasi biasanya melibatkan bakteri pereduksi sulfat (sulphate reducing bacteria) yang mampu memproduksi $\mathrm{H}_{2} \mathrm{~S}$ untuk mempresipitasi logam (Foucher et al. 2001). Bakteri pereduksi sulfat memiliki kapasitas untuk mereduksi sulfat menjadi sulfide yang kemudian bereaksi dengan logam tertentu menjadi bentuk presipitat yang tidak larut. Selain itu, sistem asiditas direduksi oleh kationnya sendiri dari reduksi sulfat dan melalui metabolisme karbon bakteri (Cao et al. 2009). Salah satu contoh mekanisme presipitasi sulfide dijelaskan sebagai berikut (Fu dan Wang 2011):

$$
\begin{aligned}
& \mathrm{FeS}_{(s)}+2 \mathrm{H}^{+}{ }_{(a q)} \rightarrow \mathrm{H}_{2} \mathrm{~S}_{(g)}+\mathrm{Fe}^{2+}{ }_{(a q)} \\
& \mathrm{M}^{2+}{ }_{(a q)}+\mathrm{H}_{2} \mathrm{~S}_{(g)} \rightarrow \mathrm{MS}_{(s) \downarrow}+2 \mathrm{H}^{+}{ }_{(a q)}
\end{aligned}
$$

\section{Bioreduksi}

Pereduksian toksik dari suatu lingkungan atau detoksifikasi dengan menggunakan mikroorganisme adalah salah 
satu pendekatan perlindungan lingkungan yang ramah lingkungan dari toksisitas yang mencemarinya. Proses bioreduksi atau biodetoksifikasi oleh mikroorganisme dapat terjadi secara langsung maupun tidak langsung. Bioreduksi secara langsung terjadi dengan melibatkan aktivitas enzimatis, sedangkan mekanisme tidak langsung melibatkan produk metabolisme (reduktan maupun oksidan) melalui reaksi reduksi oksidasi kimiawi (Wani dan Ayoola 2015). Beberapa contoh proses reduksi $\mathrm{Co}^{2+}, \mathrm{Ni}^{2+}$, $\mathrm{Cu}^{2+}$, dan $\mathrm{Cd}^{2+}$ menjadi bentuk metaliknya oleh Saccharomyces cerevisiae di dalam larutan buffer (Rahatgaonkar dan Mahore 2008), reduksi $\mathrm{Au}(\mathrm{III})$ menjadi $\mathrm{Au}(0)$ menggunakan biomassa alga cokelat Fucus vesiculosus (Mata et al. 2009), serta reduksi $\mathrm{Cr}(\mathrm{VI})$ yang bersifat karsinogen menjadi $\mathrm{Cr}$ (III) oleh bakteri Pseudomonas sp, Bacillus sp, dan sebagainya adalah contoh dari mekanisme bioreduksi logam berat (Narayani dan Shetty 2013).

\section{Bioleaching}

Bioleaching adalah suatu proses pengembalian logam dari bentuk matrik solid ke cairan yang kemudian diikuti oleh proses dekontaminasi matrik solid, berkurangnya jumlah kontaminan, serta berkurangnya paparan dan bioavailabilitas (Ohimain et al. 2009). Bioleaching juga didefinisikan sebagai proses pelarutan atau solubilisasi logam dari substrat padatan yang secara langsung dapat dilakukan melalui metabolisme mikroorganisme leaching seperti bakteri maupun secara tidak langsung yang dilakukan oleh produk metabolisme. Salah satu contoh mekanisme bioleaching dijelaskan Chen dan Lin (2001) dan pada proses bioleaching, logam berat akan mengalami proses solubilisasi, pertukaran kation, presipitasi, adsorpsi, kompleksasi, dan reaksi lainnya (Chen et al. 2005).

Mekanisme bioleaching langsung:

$$
\mathrm{MS}+2 \mathrm{O}_{2} \stackrel{\text { thiobacilli }}{\longrightarrow} \mathrm{MSO}_{4}
$$

Mekanisme bioleaching tidak langsung:

$$
\begin{gathered}
\mathrm{S}^{0}+\mathrm{H}_{2} \mathrm{O}+1,5 \mathrm{O}_{2} \stackrel{\text { thiobacilli }}{\longrightarrow} \mathrm{H}_{2} \mathrm{SO}_{4} \\
\mathrm{H}_{2} \mathrm{SO}_{4}+\text { Sedimen-M } \rightarrow \text { Sedimen-2H }+\mathrm{MSO}_{4}
\end{gathered}
$$

Mikroorganisme memiliki peran yang menentukan di dalam aliran unsur (Coleine et al. 2015) dan menjadi penggerak siklus biogeokimiawi (Burgin et al. 2011). Unsurunsur dapat mengalami proses asimilasi, degradasi, serta metabolisme senyawa organik dan anorganik seperti $\mathrm{C}, \mathrm{H}, \mathrm{O}$. Selain itu juga dapat terjadi pada unsur $\mathrm{N}$ berupa dekomposisi senyawa, denitrifikasi dan nitrifikasi, oksidasi amonia dan nitrit, atau sintesis biopolimer yang mengandung nitrogen $(\mathrm{N})$; delusi fosfat anorganik dan mineral yang mengandung fosfor $(P)$; degradasi senyawa organik yang mengandung sulfur (S); pelapukan biologis mineral yang mengandung besi (Fe), pelarutan $\mathrm{Fe}$ oleh siderofor atau asam organik dan metabolit lainnya, seperti bomineralisasi, dan oksidasi; bioakumulasi, immobilisasi, biosorpsi, presipitasi intraselular, oksidasi, reduksi, dan biomineralisasi $\mathrm{Mn}$; oksidasi, reduksi, dan akumulasi kromium (Cr); pelapukan, biosorpsi, biopresipitasi, serta penyerapan dan akumulasi pada unsur magnesium $(\mathrm{Mg})$, kalsium (Ca), kobalt (Co), nikel (Ni), seng $(\mathrm{Zn})$, dan kadmium (Cd); reduksi, biosorpsi, dan akumulasi perak (Ag); akumulasi, translokasi melalui miselium, dan mobilisasi kalium (K) dan natirum ( $\mathrm{Na}$ ); mobilisasi mineral yang mengandung tembaga $(\mathrm{Cu})$; degradasi organotin pada timah (Sn); dispersi mineral emas $(\mathrm{Au})$; volatilisasi raksa $(\mathrm{Hg})$ menjadi $\mathrm{Hg}(0)$, biometilasi $\mathrm{Hg}$, dan reduksi $\mathrm{Hg}(\mathrm{II})$ menjadi $\mathrm{Hg}(0)$; dan peran lainnya di dalam siklus mineral, termasuk proses dehalorespirasi (Gadd 2010).

\section{KESIMPULAN}

Kemampuan mikroorganisme untuk beradaptasi di dalam lingkungan ekstrem, khususnya akibat cemaran logam berat telah banyak diteliti dan diaplikasikan untuk mereduksi kontaminasi tersebut dari lingkungan. Berbagai jenis mikroorganisme, termasuk fungi dan mekanisme reduksi yang dimiliki oleh mikroorganisme tersebut dapat dimanfaatkan untuk mengendalikan cemaran di lingungan, khususnya akibat cemaran logam berat. Mikoremediasi dapat menjadi salah satu instrumen untuk mengembalikan kualitas lingkungan agar menjadi lebih baik sehingga lingkungan lebih produktif, aman, mampu memberikan jaminan kesehatan bagi 
berbagai organisme yang bergantung dengannya, serta lingkungan lestari yang dapat dikelola secara berkelanjutan.

\section{DAFTAR PUSTAKA}

Adams GO, Fufeyin PT, Okoro SE, Ehinomen I (2015) Bioremediation, biostimulation and bioaugmention: $A$ review. Int $J$ Environ Bioremediat Biodegrad 3:2839

Adenipekun CO, Lawal R (2012) Uses of mushrooms in bioremediation: $A$ review. Biotechnol Mol Biol Rev 7:6268

Agunwamba JC, Kelechi OO, Mmonwuba N (2013) Comparative analysis of bioremediation of heavy metals using plants and microorganisms. Int $\mathrm{J}$ Curr Sci 6:153-160

Ahemad M (2012) Implications of bacterial resistance against heavy metals in bioremediation: A review. J Inst Integr Omi Appl Biotechnol 3:39-46

Ahemad M, Malik A (2011) Bioaccumulation of heavy metals by zinc resistant bacteria isolated from agricultural irrigated with wastewater. Bacteriol $\mathrm{J}$ 2:1-10. doi:10.3923/bj.2011

Ahmad AK, Al-Mahaqeri SA (2015) Human health risk assessment of heavy metals in fish species collected from catchments of former tin mining. J Res Stud Sci Eng Technol 2:9-21

Akan JC, Mohmoud S, Yikala BS, Ogugbuaja VO (2012) Bioaccumulation of some heavy metals in fish samples from river Benue in Vinikilang, Adamawa state, Nigeria. Am J Analyt Chem 3:727-736. doi:10.4236/ajac.2012.311097

Akhtar MS, Chali B, Azam T (2013) Bioremediation of arsenic and lead by plants and microbes from contaminated soil. Res Plant Sci 1:68-73. doi:10.12691/plant-1-3-4

Alia N, Sardar K, Said M, Salma K, Sadia A, Sadaf S, Toqeer A, Miklas S (2015) Toxicity and bioaccumulation of heavy metals in spinach (Spinacia oleracea) grown in a controlled environment. Int $\mathrm{J}$ Environ Res Public Health 12:74007416 doi:10.3390/ijerph120707400

Anahid S, Yaghmaei S, Ghobadinejad Z (2011) Heavy metal tolerance of fungi. Sci Iran 18:502-508
Arunakumara KKIU, Xuecheng Z (2008) Heavy metal bioaccumulation and toxicity with special reference to microalgae. J Ocean Univ China 7:2530. doi:10.1007/s11802-007-0175-6

Ashraf MA, Maah MJ, Yusoff I (2011) Heavy metals accumulation in plants growing in ex tin mining catchment. Int $\mathrm{J}$ Environ Sci Tech 8:401-416

Asiriuwa OD, Ikhuoria JU, Ilor EG (2013) Myco-remediation potential of heavy metals from contaminated soil. Bull Env Pharmacol Life Sci 2:16-22

Bhatnagar S, Kumari R (2013) Bioremediation: A sustainable tool for environmental management - A review. Annu Rev Res Biol 3:974-993

Bishnoi NR, Garina (2005) Fungus - An alternative for bioremediation of heavy metal containing wastewater: A review. J Sci Ind Res 64:93-100

Boopathy R (2000) Factors limiting bioremediation technologies. Bioresour Technol 74:63-67

Bruins MR, Kapil S, Oehme FW (2000) Microbial resistance to metals in the environment Ecotoxicol Environ Saf 45:198-207

Burgin AJ, Yang WH, Hamilton SK, Silver WL (2011) Beyond carbon and nitrogen: How the microbial energy economy couples elemental cycles in diverse ecosystems. Front Ecol Environ 9:4452. doi:10.1890/090227

Cao J, Zhang G, Mao Z, Fang Z, Yang C, B Han (2009) Influence of $\mathrm{Mg}^{2+}$ on the growth and activity of sulfate reducing bacteria. Hydrometallurgy 95:127-134. doi:10.1016/j.hydromet.2008.05.006

Chaalal O, Zekri AY (2005) Uptake of heavy metals by microorganisms: An experimental approach. Energ Sources 27:87-100. doi:10.1080/009083104904 48136

Chaturvedi AD, Pal D, Penta S, Kumar A (2015) Ecotoxic heavy metals transformation by bacteria and fungi in aquatic ecosystem. World J Microbiol Biotechnol 31:1595-1603. doi:10.1007/s11274-015-1911-5

Chen S, Lin J (2001) Bioleaching of heavy metals from sediment: Significance of $\mathrm{pH}$. Chemosphere 44:1093-1102

Chen Y, Hua Y, Zhang S, Tian G (2005) Transformation of heavy metal forms 
during sewage sludge bioleaching. J Hazard Mater 123:196-202. doi:10.1016/j.jhazmat.2005.03.047

Chipasa KB (2003) Accumulation and fate of selected heavy metals in a biological wastewater treatment system. Waste Manag 23:135-143

Coleine C, Selbmann L, Ventura S, D'Acqui LP, S Onofri, Zucconi L (2015) Fungal biodiversity in the Alpine Tarfala Valley. Microorganisms 3:612-624. doi:10.3390/microorganisms3040612

Congeevaram S, Dhanarani S, Park J, Dexilin M, Thamaraiselvi K (2007) Biosorption of chromium and nickel by heavy metal resistant fungal and bacterial isolates. $\mathrm{J}$ Hazard Mater 146:270-277. doi:10.1016/j.jhazmat. 2006.12.017

Damodaran D, Suresh G, Mohan RB (2011) Bioremediation of soil by removing heavy metals using Saccharomyces cerevisiae. $2^{\text {nd }}$ International Conference on Environmental Science and Technology. Singapore

Das M, Vimala R, Karthika P (2008) Biosorption of heavy metals - an overview. Indian J Biotechnol 7:159169

Davis TA, Volesky B, Mucci A (2003) A review of the biochemistry of heavy metal biosorption by brown algae. Water Res 37:4311-4330. doi:10.1016/S0043-1354(03)00293-8

Dhakal RP, Ghimire KN, Inoue K (2005) Adsorptive separation of heavy metals from an aquatic environment using orange waste. Hydrometallurgy 79:182-190. doi:10.1016/j.hydromet. 2005.06.007

Dhokpande SR, Kaware JP (2013) Biological methods for heavy metal removal - A review. Int J Eng Sci Innov Tech 2:304309

Dixit $\mathrm{R}$, Wasiullah, Malaviya $\mathrm{D}$, Pandiyan $\mathrm{K}$, Singh UB, Sahu A, Shukla R, Singh BP, Rai JP, Sharma PK, Lade H, Paul D (2015) Bioremediation of heavy metals from soil and aquatic environment: An overview of principles and criteria of fundamental processes. Sustainability 7:2189-2212. doi:10.33 90/su70 22189

Foucher S, Battaglia-Brunet F, Ignatiadis I, Morin D (2001) Treatment by sulfatereducing bacteria of chessy acid-mine drainage and metals recovery. Chem
Eng Sci 56:1639-1645

Fu F, Wang Q (2011) Removal of heavy metal ions from wastewaters: A review. J Env Manag 92:407-418

Gadd GM (2000) Bioremedial potential of microbial mechanisms of metal mobilization and immobilization. Curr Opin Biotechnol 11:271-279

Gadd GM (2010) Metals, minerals, and microbes: Geomicrobiology and bioremediation. Microbiology 156:609643 DOI 10.1099/mic.0.037143-0

Gavrilescu M (2004) Removal of heavy metals from the environment by biosorption. Eng Life Sci 4:219-232. doi:10.1002/elsc.200420026

Gelagutashvili E. 2013. Comparative study on heavy metals biosorption by different types of bacteria. Open J Metal 3:6267. doi:10.4236/ojmetal.2013.32A1008

Gupta E, Shrivastava S (2014) Mycoremediation: A management tool for removal of pollutants from environment. Environ Sci 4:289-291

Gupta R, Mohapatra H. 2003. Microbial biomass: An economical alternative for removal of heavy metals from waste water. Indian J Exp Biol 41:945-966

Hansda A, Kumar V, Anshumali (2015) Biosorption of copper by bacterial adsorbents: A review. Res J Environ Toxicol 9:45-58. doi:10.3923/rjet. 2015.45 .58

Harms H, Schlosser D, Wick LY (2011) Untapped potential: Exploiting fungi in bioremediation of hazardous chemicals. Nat Rev Microbiol 9:177-192. doi:10.1038/nrmicro2519

Hlihor RM, Gavrilescu M (2012) Book review: Bioremediation and sustainability. Environ Eng Manage J 11:2335-2336

Iram S, Ahmad I, Javed B, Yaqoob S, Akhtar K, Kazmi MR, Uz-Zaman B (2009) Fungal tolerance to heavy metals. Pak J Bot 41:2583-2594

Iram S, Zaman A, lqbal Z, Shabbir R (2012) Heavy metal tolerance of fungus isolated from soil contaminated with sewage and industrial wastewater. Pol J Environ Stud 22:691-697

Jaiswal S (2011) Role of rhizobacteria in reduction of arsenic uptake by plants: $A$ review. J Bioremediat Biodegrad 2:1-5. doi:10.4172/2155-6199.1000126

Javanbakht V, Alavi SA, Zilouei H (2014) 
Mechanisms of heavy metal removal using microorganisms as biosorbent. Water Sci Tech 69:1775-1787. doi:10.2166/wst.2013.718

Joshi PK, Swarup A, Maheshwari S, Kumar $R$, Singh N (2011) Bioremediation of heavy metals in liquid media through fungi isolated from contaminated sources. Indian J Microbiol 51:482-487

Juwarkar AA, Misra RR, Sharma JK (2014) Recent trends in bioremediation. In: Parmar N, Singh A (eds.), Geomicrobiology and Biogeochemistry, Soil Biology 39. SpringerVerlag Berlin Heidelberg

Kensa VM (2011) Bioremediation - An overview. J Ind Pollut Contr 27:161-168

Kouba A, Buřič M, Kozák P (2010) Bioaccumulation and effects of heavy metals in crayfish: A review. Water Air Soil Pollut 211:5-16. doi:10.1007/ s11270-009-0273-8

Krishnani KK, Ayyappan S (2006) Heavy metals remediation of water using plants and lignocellulosic agrowastes. Rev Environ Contam Toxicol 188:59-84

Kulshreshtha A, Agrawal A, Barar M, Saxena $S$ (2014a) A review on bioremediation of heavy metals in contaminated water. IOSR $-J$ Environ Sci Toxicol Food Tech 8:44-50

Kulshreshtha S, Mathur N, Bhatnagar $\mathrm{P}$ (2014b) Mushroom as a product and their role in mycoremediation. AMB Express 4:1-7

Kumar A, Bisht BS, Joshi VD (2010) Biosorption of heavy metals by four acclimated microbial species, Bacillus spp., Pseudomonas spp., Staphylococcus spp. and Aspergillus niger. J Biol Environ Sci 4:97-108

Kumar A, Bisht BS, Joshi VD, Dhewa T (2011) Review on bioremediation of polluted environment: A management tool. Int J Environ Sci 1:1079-1093

Lone MI, He ZL, Stoffella PJ, Yang X (2008) Phytoremediation of heavy metal polluted soils and water: Progresses and perspectives. J Zhe Univ Sci B 9:210-220. doi:10.1631/jzus.B0710633

Mani D, Kumar C (2014). Biotechnological advances in bioremediation of heavy metals contaminated ecosystems: An overview with special reference to phytoremediation. Int $\mathrm{J}$ Environ Sci
Technol 11:843-872. doi:10.1007/ s13762-013-0299-8

Martinez RJ, Beazley MJ, Taillefert $M$, Arakaki AK, Skolnick J, Sobecky PA (2007) Aerobic uranium (VI) bioprecipitation by metal-resistant bacteria isolated from radionuclideand metal-contaminated subsurface soils. Environ Microbiol 2007:1-12. doi:10.1111/j.1462-2920.2007.01422.x

Maruthi YA, Hossain K, Thakre S (2013) Aspergillus flavus: A potential bioremediator for oil contaminated soils. Eur J Sustain Dev 2:57-66

Mata YN, Torres E, Blázquez ML, Ballester A, González F, Muñoz JA (2009) Gold(III) biosorption and bioreduction with the brown alga Fucus vesiculosus. J Hazar Mater 166:612-618. doi:10.1016/j.jhazmat.2008.11.064

Mkumbo S (2012) Development of a low cost remediation method for heavy metal polluted soils. Thesis, Royal Institute of Technology (KTH), Sweden

Mohsenzadeh F, Shahrokhi F (2014) Biological removing of cadmium from contaminated media by fungal biomass of Trichoderma species. J Environ Health Sci Eng 12:1-7

Narayani M, Shetty KV (2013) Chromiumresistant bacteria and their environmental condition for hexavalent chromium removal: A review. Crit Rev Environ Sci Technol 43:955-009. doi:10.1080/10643389.2011.627022

Ohimain El, Olu DS, Abah SO (2009) Bioleaching of heavy metals from abandoned mangrove dredged spoils in The Niger Delta; A laboratory study. World Appl Sci J 7:1105-1113

Pagnanelli F, Papini MP, Toro L, Trifoni M, Veglio F (2000) Biosorption of metal ions on Arthrobacter sp.: Biomass characterization and biosorption modeling. Environ Sci Technol 34:2773-2778

Pede A (2012) Diversity and dynamics of protist communities in subtidal North Sea sediments in relation to metal pollution and algal bloom deposition. Dissertation, Universiteit Gent, Belgia

Pinedo-Rivilla C, Aleu J, Collado IG (2009) Pollutants biodegradation by fungi. Curr Org Chem 13:1194-1214

Prakash D, Gabani P, Chandel AK, Ronen Z, 
Singh OV (2013) Bioremediation: A genuine technology to remediate radionuclides from the environment. Microbiol Biotechnol 6:349-360. doi:10.1111/1751-7915.12059

Pushkar BK, Sevak PI, Singh A (2015) Isolation and characterization of potential microbe for bio-remediating heavy metal from Mithi river. Ann Appl Bio-Sciences 2:20-27

Rahatgaonkar AM, Mahore NR (2008) A selective bioreduction of toxic heavy metal ions from aquatic environment by Saccharomyces cerevisiae. J Chem 5:918-923

Rai PK (2008) Heavy metal pollution in aquatic ecosystems and its phytoremediation using wetland plants:an ecosustainable approach. Int J Phytoremediation 10:131-58

Rajendran P, Muthukrishnan J, Gunasekaran $P$ (2003) Microbes in heavy metal remediation. Indian J Exp Biol 41:935944

Rani JM, Hemambika B, Hemapriya J, Rajeshkannan V (2010) Comparative assessment of heavy metal removal by immobilized and dead bacterial cells:a biosorption approach. Glob J Environ Res 4:23-30

Rao DV, Shivannavar CT, Gaddad SM (2002) Bioleaching of copper from chalco pyrite ore by fungi. Indian J Exp Biol 40:319-324

Remy L, Carrière $M$, Derré-Bobillot $A$, Martini C, Sanguinetti M, Borezée-Durant $E$ (2013) The Staphylococcus aureus Opp1 ABC transporter imports nickel and cobalt in zinc-depleted conditions and contributes to virulence. Mol Microbiol 87:730-743. doi:10.11 $11 / \mathrm{mmi} .12126$

Rhodes CJ (2014) Mycoremediation (bioremediation with fungi) - growing mushrooms to clean the earth. Chem Spec Bioavailab 26:196-198

Saeed SM, Shaker IM (2008) Assessment of heavy metals pollution in water and sediments and their effect on Oreochromis niloticus in the Northern Delta Lakes, Egypt. $8^{\text {th }}$ International Symposium on Tilapia in Aquaculture
2008:475-490

Samal B, Kotiyal PB (2013) Bioremediation of copper contaminated soil using bacteria. Oct J Environ Res 1:5-8

Sayyed RZ, Patel PR (2011) Soil microorganisms and environmental health. Int J Biotechnol Biosci 1:41-66

Singh A, Sharma R (2013) Mycoremediation an eco-friendly approach for the degradation of cellulosic wastes from paper industry with the help of cellulases and hemicellulase activity to minimize the industrial pollution. Int $\mathrm{J}$ Environ Eng Manag 4:199-206

Siswati ND, Indrawati T, Rahmah M (2009) Biosorpsi logam berat plumbum (Pb) menggunakan biomassa Phanerochaete chrisosporium. J IIm Tek Lingkung 1:67-72

Smical A, Hotea V, Oros V, Juhasz J, Pop E (2008) Studies on transfer and bioaccumulation of heavy metals from soil into lettuce. Environ Eng Manag J 7:609-615

Tangahu BV, Abdullah SRS, Basri H, Idris M, Anuar N, Mukhlisin M (2011) A review on heavy metals (As, $\mathrm{Pb}$, and $\mathrm{Hg}$ ) uptake by plants through phytoremediation. Int $\mathrm{J}$ Chem Eng 2011:1-31. doi:10.1155/2011/939161

Verma DK, Gupta AP (2011) Removal of heavy metals from whole sphere by plants working as bioindicators - a review. Basic Res. J Pham Sci 1:1-7

Wang X, Guo Y, Yang L, Han M, Zhao J, Cheng $X$ (2012) Nanomaterials as sorbents to remove heavy metal ions in wastewater treatment. J Environ Anal Toxicol 2:1-7. doi:10.4172/21610525.1000154

Wani PA, Ayoola OH (2015). Bioreduction of $\mathrm{Cr}$ (VI) by heavy metal resistant Pseudomonas species. J Environ Sci Technol 8:122-130. doi:10.3923/jest.2015.122.130

Yin H, Niu J, Ren Y, Cong J, Zhang X, Fan F, Xiao $Y$, Zhang $X$, Deng J, Xie M, He Z, Zhou J, Liang Y, Liu X (2015) An integrated insight into the response of sedimentary microbial communities to heavy metal contamination. Sci Rep 5:1-12. doi:10.1038/ srep14266 